\title{
Outlook for the Development and Technology of Petrochemical Industry in Japan*
}

\author{
Shinpachiro Kato**
}

\section{The Development of Petrochemical Industry in Japan}

Japan's petrochemical industry started its activities with the production of solvents in 1955 by oil interests about 30 years behind the I $i . S$. petrochemical industry which dates back as early as 1920's. Subsequently, fullscale petrochemical industry with naphtha cracking facility (ethylene plant) as its core was started in Japan around 1956 by chemical companies formerly under Zaibatsu combine.

In its initial stage (1955-1957), however, the petrochemical industry in Japan was small in size and undoubtedly lacked competitive power, with cpacity of each ethylene plant as follows:

\begin{tabular}{c|cc}
\hline Name of Company & Capacit! & $\begin{array}{c}\text { Date of } \\
\text { Plant } \\
\text { Completion }\end{array}$ \\
\hdashline $\begin{array}{c}\text { Mitsui Petrochemical } \\
\text { Industires (Iwakuni) } \\
\begin{array}{c}\text { Mitsubishi Petrochemical } \\
\text { Co. (Yokkaichi) }\end{array}\end{array}$ & 20,000 & Feb. 1958 \\
$\begin{array}{c}\text { Sumitomo Chemical lu. } \\
\text { (Niihama) }\end{array}$ & $22,800 "$ & May 1959 \\
\hline
\end{tabular}

Thenceforth, supported by the growing demand for ethylene derivatives, particularly for such general purpose plastics as polycthylene, polystyrene, etc., the ethylene plants which constitute the mainstay of petrochemical industry were expanded; on the other hand, many organic chemicals co-produced by the ethylene plants have secured their positions as low-cost raw materials in many industries. The petrochemical industry in Japan has, thus, made steady progress.

With the development of the petrochemical industry, not a few conventional chemical products have come to depend upon the petrochemical industry for their raw materials and such switch-over in the source of raw materials has stimulated the advancement of related technologies. These circumstances have continued to prevail up to the present.

Eleven ethylene centers, including both earlystarter's and latestarter's, are now in operation; the aggregate of their production amounts to $1,443,800 \mathrm{t} / \mathrm{yr}$ as of October 1967.

At this point we wish to review the present situation of petrochemical industry in Japan.

On the basis of imported foreign technologies, Japan's petrochemical industry has made a satisfactory growth without much difficulty.

As stated above, induction of high-level processes from the U.S. and, Europe prompted switchover of raw materials in Japanese chemical industry, thus making a great contribution to the improvement of the living conditions up to the present level. Pisides the output of the petrochemical indsutry for fiscal 1966 so much increased as to share more than $22^{\circ}$ of that of the entire Japan's chemical industry.

The petrochemical industry has been developed up to the present with clothes and housing as its main field of application. With little change in such tendency, the petrochemical industry will continue to increase its weight as a key industry.

Table 1. Comparison of Production between Petrochemical Industry and Entier Chemical Industry

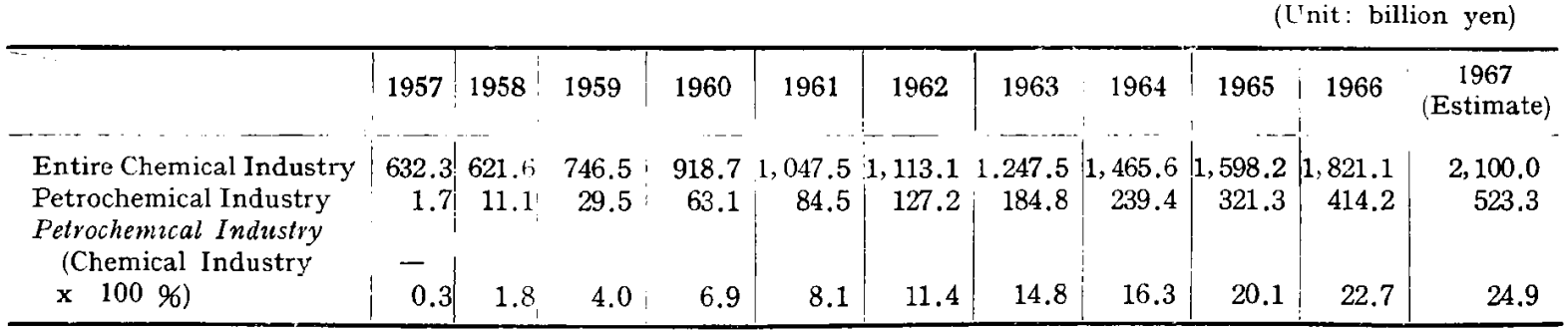

(The production of petrochemicals presently occuupies about a quarter of that of entire chemical industry)

* Recieved December 28, 1967. 
As already reviewed, Japan's petrochemical industry has attained a high-pitched growth to

Table 2. Investment in Petrochemical Industry

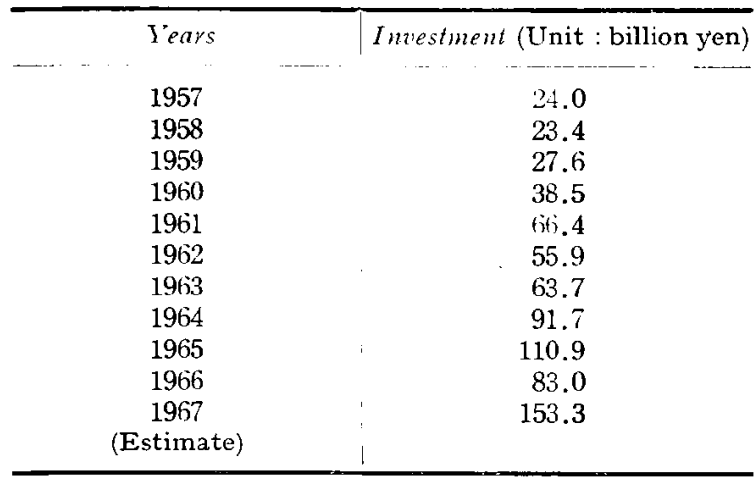

* Owing to the Government's investment coordination policy enforced in 1966, the investment amount decreased compared with the previous year.)

Table 3 Transition of the Government's Standard on Valdiation Ethylene Plant

\begin{tabular}{|c|c|c|}
\hline Year & & $\begin{array}{c}\text { Capacity } \\
\text { (one unit) } t / y\end{array}$ \\
\hline 1958 & $\begin{array}{l}\text { (Initial Stage of Petrochemical } \\
\text { Industry) } \\
\text { (Decision as a Result of Consul- }\end{array}$ & 20,000 \\
\hline 1961 & $\begin{array}{l}\text { tation on Basic Problems Re- } \\
\text { garding Chemical Industry) } \\
\text { (Decision of Industrial Structure }\end{array}$ & 50,000 \\
\hline 1963 & Investigation Committee) & 100,000 \\
\hline 1967 & $(*)$ & 300,000 \\
\hline
\end{tabular}

* (As to the ethylene plant with $300,000 \mathrm{t} / \mathrm{y}_{\text {r }}$ capacity, the project of Maruzen Petrochemi. cal has been approved by MITI ; furthermore, Ukishima Petrochemical has been approved by MITI; furthermore, Ukishima Petrochemical (a joint venture company of Mitsui Petrochemical Industries and Nippon Petrochemicals), Kashima Petrochemicals, Sumitomo Chemical, Osaka Petrochemicals, Kasei Mizushima, etc. have announced respectively each of their $300,000 \mathrm{t} / \mathrm{y}_{r}$ projects.)

Ehylene Centers and Their Principal Associate Companies

(Ethylene Capacity as of October 1967)

(1) Mitsui Petrochemical

Industries, Ltd

(Iwakuni Ohtake)

Ethylene Capacity

Principal Associate

Companies:

(2) Mitsui Petrochemical

Industries, Ltd. (Chiba)

Ethylene Capacity :

$120,000 \mathrm{t} / \mathrm{y}_{r}$ Koa Oil Co., Jtd. (supplier of naptha) Mitsui Polycehmical Industries, Ltd. (highpressure polyethylene; Mitsui Petrochemical-Du Pont, joint venture Dainippon Chemical Co.. Ltd. (acetic acid, etc.) Mitsui Chemical Industry Co., Ltcl. (Polypropylene)
Principal Assoociate Companies :

(3) Sumitomo Chemical

Co., Ltd. (Niihama)

Ethylene Capacity :

Principal Associate

Company :

(4) Sumitomo Chemical Co., Ltd. (Chiba) Ethylene Capacity : Principal Associate Company : mical (o. (Yokkaichi) Ethylene Capacity Principal Associate Companies :

(6) Nippon Petrochemicals Co., Ltd.

(Kawasaki)

(Subsidiary of Nippon Oil Co., Ltd.) Ethylene Capacity : Principal Associate Companies :

(7) Tonen Petrochemicals Co., Ltd. (Kawasaki) (Subsidiary of Toa

Nenryo K.K.)

Ethylene Capacity : Principal Associate Companies :
(5) Mitsubishi Petroche-

Kyokuto Petroleum Industires, Ltd. (sup plier of naphtha)

Mitsui Polychemical Industries, Ltd. (highpressure polyethylene)

$111,500 \mathrm{t} / \mathrm{r}_{r}$

Idemitsu Kosan Co., I.td (supplier of naphtha.)

$100,000 \mathrm{t} / \mathrm{y}$,

Idemitsu Kosan Co., Ltd.

(supplier of naphtha)

$182.000 \mathrm{t} / \mathrm{y}$,

Showa Yokkaichi Sekiyu Co., Ltd. (supplier of naphtha)

Japan Synthetic Rubber Co., Itd.

Mitsubishi Edogawa Chemical Co., Ltd.

Mitsubishi Monsanto Chemical Co., Ltd.

$200,000 \mathrm{t} / \mathrm{y}$

Nippon Petroleum Refining Co., Ltd. (supplier of naphtha)

(Joint Venture of Nippon Oil Co., Ltd. and California Texas Oil Corp.)

Showa Denko KK.

Furukawa Chemicals Co., Ltd.

Japan Catalytic Chemical Industry Co., Ltd.

Asahi Chemical Industry Co., Ltd.

Asahi-Dow, Ltd.

Nippon Soda Co., Ltd Nippon Synthefic Alcohol Co., Ltd.

$180,000 \mathrm{t} / \mathrm{y}$,

\section{$205,000 \mathrm{t} / \mathrm{y}$,}

Toa Nenryo Kogyo, K.K. (supplier of naphtha)

Tokyo Gas Co., Ltd.

Nippon Unicar Co., Ltd. Asahi-Dow, Ltd.

Nippon Olefin Chemicals Co., Ltd.

The Japanese Geon Co., Ltd.

Showa Denko K.K.

Asahi Chemical Industry Co., Ltd.

Central Chemicals, Ltd.

Nippon Synthefic Alchol Co. Ltd. 


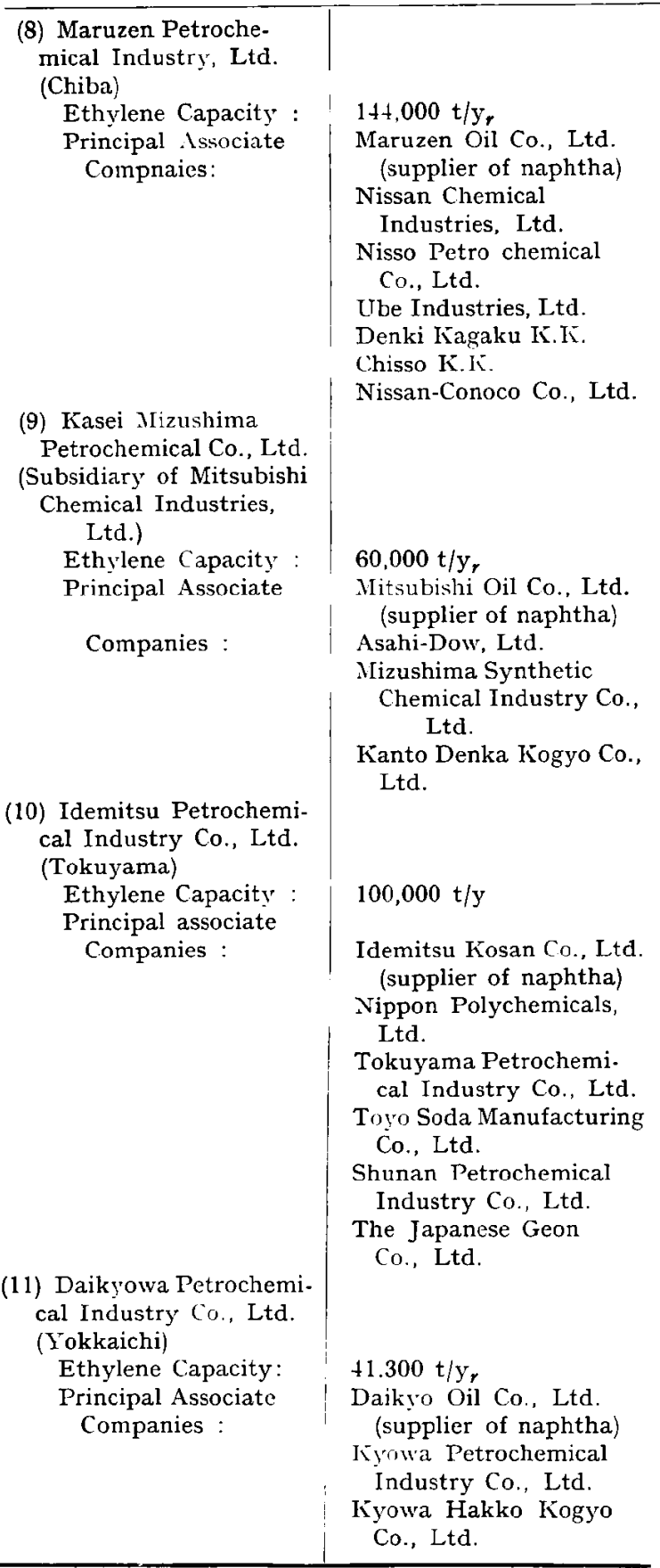

date. However, now that petrochemical industry is no exception among industries to be affected by the capital liberalization, development of the domestic technology is earnestly desired.

\section{The Infuence of Petrochemical Industry over Other Industries}

Originally, Japan's petrochemical industry fell far behind that of the U.S. and Europe in the technological aspect because of the handicap caused during the Second World War. In order to fill this gap most of technologies concerning
Principal Petrochemical Products and Production Capacity

\begin{tabular}{|c|c|}
\hline Product & $\begin{array}{l}\text { Production Capacity for } \\
\text { Fiscal } 1966 \text { (Estimated) }\end{array}$ \\
\hline Ethylene $\ldots \ldots \ldots \ldots$ & $\begin{array}{c}\left(t / y_{r}\right) \\
1,443,800\end{array}$ \\
\hline $\begin{array}{l}\text { Polycthylene } \ldots \ldots \ldots \ldots \\
\text {. }\end{array}$ & 774,000 \\
\hline Ethylene oxide & 165,000 \\
\hline Ethylene glycol & 135,000 \\
\hline Styrene (Monomer) ...... & 325,000 \\
\hline Polystyrene $\ldots \ldots \ldots \ldots$ & 220,700 \\
\hline Acetaldehyde ......... & 241,500 \\
\hline Butanol ............. & 89,400 \\
\hline Ethyl alcohol $\ldots \ldots \ldots$ & 20,000 \\
\hline EDC $\ldots \ldots \ldots$ & 244,900 \\
\hline Acetic acid $\ldots \ldots \ldots$ & 143,000 \\
\hline Polypropylene ........ & 116,000 \\
\hline Alkyl benzene ......... & 112,000 \\
\hline Acrylonitrile . . . . . . . . . & 173,000 \\
\hline Isopropyl alcohol $\ldots \ldots$. & 17,500 \\
\hline Octanol $\ldots \ldots \ldots \ldots \ldots$ & 48,400 \\
\hline MIBK $\ldots \ldots \ldots \ldots \ldots$ & 14,400 \\
\hline Phenol & 52,800 \\
\hline Epoxy resin. & 8,000 \\
\hline Butadiene.. & 182,000 \\
\hline Synthetic rubber & 236,000 \\
\hline MEK . . . . . . . & 11,000 \\
\hline Benzene $\ldots$ & 377,200 \\
\hline Toluene & 243,200 \\
\hline Xylene $\ldots \ldots$ & 158,800 \\
\hline Terephthalic acid . . . . . & 116,800 \\
\hline
\end{tabular}

petrochemical industry were introduced into Japan. On the other hand, vigorous efforts were also made for the improvement of these foreign technologies with the result of commercialization of indigenous technologies which are increasing year after year.

In the following, we will survey the transition of relevant technologies as well as the influence of the growth of petrochemical industry upon principal chemical industries.

\subsection{Fertilizer Industry}

The petrochemical industry gave a great influence upon fertilizer industry in a sense that it brought about the conversion of raw materials for synthesized ammonia which had till then depended only upon solid materials such as coke and coal, and electric power. Japan GasChemical, however, succeeded in synthesizing ammonia by using natural gas as the raw material, which was followed by Sumitomo Chemical (waste gas from naphtha cracking) and Nissan Chemical Industry (heavy oil, crude oil). All these companies subsequently again switched to naphtha as the source of raw material.

Such conversion of raw materials prompted the development of the technologies suitable for a large-scale plant, and the plants with 500-700 $t /$ day capacity were constructed: it is not unreason- 
Coversion of Raw Materjahs for Synthesjzed Ammonja

(Unit : $10^{\text {t } t}$ )

\begin{tabular}{|c|c|c|c|c|c|c|c|c|c|c|}
\hline \multirow[b]{2}{*}{ Yeat } & \multicolumn{5}{|c|}{ Solid Raw Material } & \multicolumn{5}{|c|}{ Liquid Raw Material } \\
\hline & $\begin{array}{c}\text { Elecro- } \\
\text { lytic } \\
\text { Process }\end{array}$ & $\begin{array}{c}\text { Coke } \\
\text { Process }\end{array}$ & $\begin{array}{l}\text { Winkler } \\
\text { Process }\end{array}$ & $\begin{array}{l}\text { Powder } \\
\text { coal } \\
\text { Gasifi- } \\
\text { cation } \\
\text { Process }\end{array}$ & Total & $\begin{array}{c}\text { Coke } \\
\text { Oven } \\
\text { Gas } \\
\text { Process }\end{array}$ & $\begin{array}{c}\text { Crude Oil } \\
\text { Gasifi. } \\
\text { cation } \\
\text { Process }\end{array}$ & $\begin{array}{l}\text { Natural } \\
\text { Gas } \\
\text { Process }\end{array}$ & $\begin{array}{c}\text { Petroleum } \\
\text { Waste Gas } \\
\text { Process }\end{array}$ & Total \\
\hline 1955 & 25 & 40 & 20 & 10 & 70 & 5 & & 15 & & 5 \\
\hline 1960 & 10 & 15 & 10 & 5 & 30 & 12.5 & 25 & 17.5 & 7.5 & 60 \\
\hline 1965 & 2.5 & & 5 & & 5 & 17.5 & 50 & & 7.5 & 92.5 \\
\hline
\end{tabular}

able to expect that ammonia plants having as large as $1,000 \mathrm{t} /$ day capacity will be realized before long.

2.2 Carbide Industry

Carbide industry was most seriously affected by the development of petrochemical industry in the aspect of raw materials conversion.

2.2.1 Polyingl Chloride

Blessed with the abundant resources of lime stone and hydroelectricity, Japan's polyvinyl chloride industry achieved a great development with its product having a wide range of application. The production of PVC is estimated to be more than 600,000 tons in 1967 .

Diversified technologies of manufacturing vinyl chloride,ranging from the most primitive process (acetylene process) to the up-to-date process (oxychlorination process), coexist now in Japan. However, because of the availability of ethylene at low cost, the latter process is gradually replacing the former one. All the future vinyl chloride plants will certainly adopt the oxychlorination process or a process (Kureha process) that uses naphtha as the raw material except where manufacutrers have advantages of their unique raw material availabilities.

\subsubsection{Acetaldehyde}

Like PVC, acetaldehyde has come to be manufactured by a process of direct ethylene oxidation instead of the conventional process which uses acetylene as the raw material. There is a great demand for acetaldehyde as the raw material of acetic acid. All the plants in Japan other than the one plant, i.e., Ome Plant of Denki Kagaku Kogyo, have switched their process to ethylene process; but the said plant will also adopt ethylene process in the near future.

\subsubsection{Vinyl Acitat?}

Vinyl acetate holds the demand amounting to 2,800 million tons per year, most of which is processed into polyvinylformal fiber.

Compared with the aforementioned PVC and acetaldehyde, rinyl acetate showed the most delay in the raw material conversion. However, since the beginning of 1967, the industry has indicated active move of switching from acetylene process to ethylene process, and almost all the expansions of plant capacity are being projected to employ ethylene process. Thus, there is no doubt about the complete switch-over to ethylene process in future.

\subsection{Rubber Industry}

Japan's synthetic rubber industry was founded when Japan Synthetic Rubber Co. commenced the commercial production of SBR in 1960. Since the establishment of petrochemical industry in 1958 with ethylene production by naphtha cracking as its basis, the raw materials of synthetic rubber, such as butadiene and styrene, have become available; under the circumstances, SBR has first been commercialized, followed by polybutadiene. On the other hand, the commercialization of special synthetic rubbers, e.g., nitrile rubber, chloroprene, etc., has also been materialized by other companies.

The development of petrochemical industry has enabled Japan's synthetic rubber industry to advance very rapidly, and its production capacity is now only next to the U.S. in the world.

Although the development of Japan's synthetic rubber industry is largely attributable to the inducted foreign technologies, Denki Kagaku Kogyo's technology developed by themselves for the manufacture of chloroprene by acetylene or butadiene process is highly appraised by the circles concerned.

\subsection{Synthetic Fiber Manufacturing Industry}

Petrochemical industries have enabled us to obtain in a large quantity all of the three major synthetic fibers, namely, polyester, polyamide and acrylic fiber. Synthetic fibers synthesized from ethylene, propylene and aromatics have come to occupy $31 \%$ of all the fibers that are being manufactured today in Japan. 


\subsubsection{Polvamide Fiber}

Contrary to the U.S. and European countries where nylon 66 has been a main product as polyamide fiber, this segment of fiber industry in Japan has made progress centering on nylon 6 . Only recently, production of nylon 66 was started on a small scale.

It may be said that the transition of processes for manufacturing caprolactum as monomer for nylon 6 reflects the trend of technologies employed in the manufacture of polyamide fiber in Japan. Phenol Process in which phenol is utilized as starting raw material was predominant at the early stage of caprolactum manufacture. Subsequently, there emerged Cyclohexane Process in which cyclohexane is directly oxidized, and this process has been predominant in Japan up to the present time. In the meantime, PNC Process was developed and commercialized by Toyo Rayon Co., Ltd., which aroused world-wide sensation.

On the other hand, the commercial production of nylon 66 was delayed for the reason that nylon 66 would not be competitive with nylon 6 in price. It was in 1966 that Toyo Rayon Co., Ltd. began manufacturing nylon 66 on a small scale. There are several other fiber manufacturing companies in Japan that are planning to manufacture this type of nylon commercially.

2.4.2 Polyester Fiber

Ethylene glycol and terephthalic acid (or DMT) are the raw materials for polsyester fiber. As for ethylene glycol, we can cite SD Process and Shell Process that arc considered to be substantially of the same type since direct oxydization of ethylene is common to both processes.

Our discussion will, therefore, be focused on TPA-manufacturing processes. The processes adopted in Japan comprise Henkel Process (1st \& 2nd), Mid-Century Process, Grosskinsky Process and Witten Process. Predominant among those processes is Mid-Century Process which is based on air oxidation with paraxylene as raw material. Although Grosskinsky Process was commercialized by Toyo Koatsu Industries, Inc., its plant operation is being suspended.

\subsection{Ditergent Industry}

Soap has been the main item of detergents for years in the past. Due to extensive use of electric washing machines, however, synthetic detergent based on alkylbenzene sulfonates has rapidly grown into a product of sizeable sales volume.

Later, hard-type detergent based on alkylben- zene as raw material gave rise to the problem of public nuisance in Europe and in the U.S. due to its poor biodegradability and physical interference with operation of the sewage disposal facilities. Repressions of such social issues abroad came to be felt in Japan and arrangements for effectuating switchover to soft-type detergent are being established in Japan. Such move is represented by normal paraffin commercialization planned by Nippon Mining Co., Ltd., Mitsui Petrochemical Industries, Ltd., Idemitsu Petrochemical Company, Ltd., Nippon petrochemicals Co., Itd. etc. Furthermore, "Switch-to-Soft-Type" trend spur red on the shift to petrochemical method in the manufacture of higher alcohol which had been dependent on reduction of natural cocooil. Thus, Nissan Chemical Industries, Ltd. will shortly start up its Oxo Process Plant, and furthermore Mitsui Petrochemical Industries, Ltd., Kao Soap Co., Ltd., Mitsubishi Petrochemical Co., Ltd., etc. are planning a commercial production of higher alcohol.

2.6 Plastics,

When petrochemical industry was introduced into Japan, there had already been about 50,000 t/yr demand for polyvinyl chloride as general purpose plastics.

Following induction from abroad of technologies for petrochemicals manufacture, polyethylene and polystyrene were the first items commercially produced in Japan. Those general purpose plastics rapidly penetrated into the areas of sundry goods as the mainstay and also some other areas closely related to human living. They also found increasing usage as engineering plastics in the areas of construction materials, electric appliances, machinery, etc. Such remarkable development of those plastics is, needless to say, attributable to the supply of raw material for plastics such as ethylene, styrene, phenol, propylene, etc. at lower cost by virtue of petrochemical technologies and to the development of resin-processing technologies based on what was inducted from foreign countries. Besides, we can not overlook development of new technologies which also played an important role. More specifically, we may mention the emerging of inter-plastisized polyvinyl chloride, new or reformed polymer such as $\mathrm{ABS}, \mathrm{AS}$, etc, by dint of copolymerization, and also epochmaking isotactic copolymer (such as polyolefin, propylene copolymer, etc.). 